\title{
ACETYLCHOLINESTERASE, AS A POTENTIAL BIOMARKER OF NAPHTHALENE TOXICITY IN DIFFERENT TISSUES OF FRESHWATER TELEOST, ANABAS TESTUDINEUS
}

\author{
Susri NAYAK, Lipika PATNAIK \\ Center of Excellence in Environment and Public Health, Environmental Science Laboratory, \\ Department of Zoology, Ravenshaw University, Cuttack 753008, Odisha, India
}

Received 28 October 2020; accepted 05 February 2021

\begin{abstract}
Highlights
Naphthalene was found to have an inhibitory effect on the activity of acetylcholinesterase in the tissues of the brain, liver, muscles, and gill of Anabas testudineus.

$>$ AChE activity decreased in a dose-dependent manner and the same was not observed in the case of the control set.

$>$ Range of inhibition of AChE was between - 9.34-43.95\% in brain tissues, $2.56-35.81 \%$ in liver tissue, $5.94-34.15 \%$ in muscle tissue and $3.92-33.75 \%$ in gills.

Lower AChE enzyme activity observed in the tissues of experimental animal.

$>$ AChE enzyme activity may be used as biomarkers tool for assessing neurotoxicity and environmental health.
\end{abstract}

\begin{abstract}
Naphthalene, a Polycyclic Aromatic Hydrocarbon is widely used as a fumigant and disinfectant despite its toxic effect and is ranked as the ninth most threatening compound. The present study was carried out to determine the in vivo effect of naphthalene at different concentrations on acetylcholinesterase (AChE) enzyme activity in different tissues of Anabas testudineus. The fishes were exposed to varying concentrations of naphthalene $\left(4.2 \mathrm{mgL}^{-1}, 4.4 \mathrm{mgL}^{-1}, 4.6 \mathrm{mgL}^{-1}\right.$, $4.8 \mathrm{mgL}^{-1}$ and $5 \mathrm{mgL}^{-1}$ ) for a period of 72 hours. Acetylcholinesterase enzyme activity was found to be significantly inhibited, in a dose-response manner. The inhibition percentage of AChE activity varied from 9.34-43.95\% in brain tissue, $2.56-35.81 \%$ in liver tissue, $5.94-34.15 \%$ in muscle tissue and $3.92-33.75 \%$ in gills in comparison to the tissues of the control group. Maximum inhibition of acetylcholinesterase enzyme activity in treated fish was observed in the brain followed by liver, muscles, and gills. This study highlights the significance and role of acetylcholinesterase as a potential stress biomarker of naphthalene toxicity.
\end{abstract}

Keywords: naphthalene, polycyclic aromatic hydrocarbons, Anabas, acetylcholinesterase, biomarker, environmental monitoring.

\section{Introduction}

Polycyclic Aromatic Hydrocarbons (PAHs), are the ninth most commonly distributed persistent organic pollutant group (POPs) capable of causing health hazards (Armstrong et al., 2004). PAHs comprise of carcinogenic and mutagenic forms and are included in the European Union and the United States Environmental Protection Agency (EPA) (Hossain et al., 2014; Latimer \& Zheng, 2003). Constant discharge of these persistent organic pollutants into the aquatic ecosystem often leads to various contaminations and has been reported to affect the water quality. Aquatic fauna, both invertebrates, and fishes have been reported to demonstrate toxicity as a result of direct contact with contaminants (Vijayavel et al., 2006; Ansari et al., 2010; Dey et al., 2019), as a result of which these animals are extensively used in acute and chronic toxicity research. Organisms get exposed to PAHs in a complex mixture form often leading to either synergistic or antagonistic effect. Fishes are extremely sensitive to various contaminants as they can accumulate a variety of lipophilic organic contaminants and are also competent in using various defensive cellular mechanisms against toxic compounds. Biomarkers are measurable response signifying the first level of biological organization and have

${ }^{*}$ Corresponding author. E-mail: lipika_pat@yahoo.co.uk 
been used for evaluating exposure impact (Walker et al., 2012; Pikarainen, 2006). Therefore, identifying biomarkers in fish species may perhaps help to evaluate the level of toxicity due to the presence of PAHs in surrounding environments (Zulfahmi et al., 2018; Mary et al., 2014). Naphthalene has been one of the extensively studied PAH because of its high toxicity and its lower molecular weight (Palanikumar et al., 2013). It is introduced in the environment run-offs from coal-tar production and distillation units. Domestic use of naphthalene is in the form of mothballs, fumigants, and cleaning solutions. In India, the use of mothballs is very common and is found everywhere as there is no public information about the possible impact of naphthalene. High temperature coal tar derived from steel industry contains various organic chemicals such as naphthalene, xylene, toluene etc. The other broader application of naphthalene can be seen in various sectors like textile Industry as a wetting agent during the scouring operation and dyeing (Shenai, 2001; Sivaram et al., 2019; Mehra \& Chadha, 2020) and preparation of wall tiles for water proofing system (Aly et al., 2018; Balkumaran et al., 2015). It is an important raw material for the production of sulfonated naphthalene formaldehyde (SNF) and SNF is used for increasing the fluidity of concrete mixtures (Zhang et al., 2019). Continuous release and accumulation of naphthalene with its by-products is capable of inducing toxicity and affect the aquatic ecosystem. Acetylcholinesterase is found at neuromuscular junctions, cholinergic synapses, and has also been reported to be present in erythrocytes and organs like the liver and muscles (Gupta et al., 2017). Acetylcholinesterase is an important biochemical biomarker along with GST, CAT, and LPO (de Castilhos Ghisi, 2012). Brain and muscle tissue of fish generally contain AChEs, while liver and plasma contain Butyrylcholinesterases (BChEs) (Fulton \& Key, 2001). BChE indirectly helps in detoxification and probably protects $\mathrm{AChE}$ from anticholinesterasic agents (Whittaker, 1980). AChE signifies the combined activity of Butyrylcholinesterase and Acetylcholinesterase found in muscles. The increased exposure can lead to a decrease in the activity of AChE. Several literatures have reported the various toxicity effects of naphthalene in aquatic animals (Vijayavel et al., 2006; Ansari et al., 2010). Hauser-Davis et al. (2019) observed that the activity of AChE is inhibited by PAHs in mullet. They reported that 2-Naphthol was a less potent AChE inhibitor compared to Naphthalene and mullet brain extracts can be used to analyze the neurotoxic effect of PAHs on fish AChE. Similar results pertaining to inhibition of AChE in Nile tilapia exposed to textile industry effluent has been discussed in a review paper by Athira and Jaya (2018) and they have highlighted the role of fish biomarker for understanding the effect of contaminants found in textile effluent. However, very scarce information is available related to AChE activity as a result of naphthalene exposure in Anabas testudineus. The objective of the present investigation was to study the effect of naphthalene on AChE activity in different tissues of Anabas testudineus. AChE is a functional biomarker which can be used in different animal systems to understand the effect of xenobiotics and its study is important as it acts as a stress responder. Response of AChE can be integrated and correlated with antioxidant defense mechanism along with lipid peroxidation level to observe the results of toxicant exposure.

\section{Materials and methods}

\subsection{Fish collection and acclimatization}

Anabas testudineus with an average weight of $11.2 \pm 0.62$ grams and length $11.2 \pm 0.10 \mathrm{~cm}$ were obtained from CIFA (Central Institute of Freshwater Aquaculture) Bhubaneswar, Odisha, India. Fishes were stocked in 50L glass aquariums and acclimatized in laboratory conditions for two weeks. During the acclimatization period the physicochemical properties of water $(\mathrm{pH} 7.56 \pm 0.10$, temperature $22.60 \pm 0.39^{\circ} \mathrm{C}$, dissolved oxygen $5.12 \pm 0.57 \mathrm{mgL}^{-1}$, total hardness $161.2 \pm 0.87 \mathrm{mgL}^{-1}$ and alkalinity of $146.4 \pm 0.76 \mathrm{mgL}^{-1}$ ) was constantly monitored using standard protocols (American Public Health Association [APHA], 2005). The fishes were fed dry commercial feed having $45 \%$ protein regularly once a day. However, feeding was stopped $24 \mathrm{hrs}$ before carrying out toxicity tests.

\subsection{Acute toxicity $\left(\mathrm{LC}_{50}\right)$}

Toxicity tests were carried out initially to determine $\mathrm{LC}_{50}$ of naphthalene after 72 hours. Separate glass aquariums $(50 \mathrm{~L})$ were taken and different concentrations of naphthalene ranging from $0.1 \mathrm{mgL}^{-1}$ to $5.4 \mathrm{mgL}^{-1}$ were added. 20 healthy fish were collected from the stock and introduced into each aquarium. Triplicates were maintained for each concentration along with a separate control set. Naphthalene was procured from Central Drug House (CDH), New Delhi, India, and was dissolved in acetone. The mortality rate was calculated taking into account the number of dead fishes after 72 hours of exposure. The $\mathrm{LC}_{50}$ for naphthalene was determined by the graphical and probit analysis method (Finney, 1971).

\subsection{Experimental design}

For experimental dose duplicate sets $(n=6)$ were maintained for each concentration. The experiment was done using $25 \mathrm{~L}$ of water and the capacity of the aquarium was $50 \mathrm{~L}$. Dose concentrations used for the experimental work were $4.2 \mathrm{mgL}^{-1}, 4.4 \mathrm{mgL}^{-1,} 4.6 \mathrm{mgL}^{-1}, 4.8 \mathrm{mgL}^{-1}$ and $5 \mathrm{mgL}^{-1}$. Feeding was stopped one day before exposure to toxicity tests. Acetone was used as a carrier to dissolve naphthalene in water. The fishes were not fed during the exposure period of the experiment and the toxicant in the medium was not renewed following the guidelines of static toxicity test.

\subsection{Water analysis}

Water temperature, $\mathrm{pH}$, dissolved oxygen, water hardness, and alkalinity were regularly kept in check using standard 
methods (APHA, 2005). Naphthalene concentration in the experimental tank was confirmed and detected using High-performance liquid chromatography (HPLC). The water samples were collected in amber colored Tarson sample containers having a capacity of $1000 \mathrm{ml}$ and for each dose a duplicate set was maintained. The water samples were filtered through a $0.45 \mu \mathrm{m}$ microporous filter membrane to remove any suspended particles. The filtered water samples were transferred into a separating funnel and a mixture of $100 \mathrm{ml}$ of $\mathrm{n}$-hexane and dichloromethane was added and stirred for 2 minutes. Samples were extracted within 48 hours using $\mathrm{n}$-hexane and dichloromethane. The water phase was drained and the organic phase was transferred into a glass funnel containing $20 \mathrm{~g}$ of anhydrous sodium sulphate and reextracted with $50 \mathrm{ml}$ of the same solvent mixture. The extract was concentrated prior to PAH analysis. Naphthalene residues were analyzed by High-Performance Liquid Chromatography (HPLC), with a UV detector set at $275 \mathrm{~nm}$, an automatic injector with a capacity of 20 $\mu \mathrm{l}$, and a reverse-phase symmetry column. The mobile phase was methanol and ultrapure water in the ratio of $80: 20$ at a flow rate of $1 \mathrm{~mL} / \mathrm{min}$, and the injector volume was $20 \mu \mathrm{L}$.

\subsection{Homogenate preparation and $\mathrm{AChE}$ activity assay}

Tissues like brain, gill, liver, and muscle were removed from the experimental $(n=6 \times 2)$ and control $(n=6 \times 2)$ fishes after 72 hours of exposure for analysis of AChE activity. The tissues were excised and cleaned in an icecold saline solution $(0.85 \%)$. They were homogenized in $2 \mathrm{ml}$ of Tris - HCL ( $\mathrm{pH} 7.5,0.1 \mathrm{M}$ ) using a precooled homogenizer with a serrated pestle (HiMedia Laboratories, Mumbai, India) at $4^{\circ} \mathrm{C}$. The homogenate was centrifuged at $1200 \mathrm{rpm}$ for 15 minutes and the supernatant was used to determine enzyme activity. The reaction mixture $(3.0 \mathrm{ml})$ consisted of $0.5 \mathrm{M}$ Tris- $\mathrm{HCl}$ buffer ( $\mathrm{pH}$ 7.5), $1 \mathrm{mM}$ DTNB, $0.1 \mathrm{mM}$ acetylcholine chloride and $100 \mu \mathrm{l}$ of tissue supernatant. The rate of AChE activity was measured spectrophotometrically at an interval of 30 seconds for 5 minutes at $412 \mathrm{~nm}$ (Ellman et al., 1961). The AChE activity was expressed as nmole (product) formed $/ \mathrm{min} / \mathrm{mg}$ of protein. Protein was determined using bovine serum albumin as a standard (Lowry et al., 1951).

\subsection{Statistical analysis}

Data were presented as mean \pm SEM. Results were compared using one-way analysis of variance (ANOVA) ( $p<0.05$ was found to be statistically significant) followed by Dunnett's test using a statistical software GraphPad Prism 5. Dunnett test was used for comparing mean from multiple experiment groups against a control group to elucidate difference if any and has been used after running the ANOVA for identification of pairs with significant differences. At the initial stage data was tested for normality and homogeneity of variance by Levene's test. This was followed by One way ANOVA and Dunnet's post-hoc test.

Table 1. ANOVA result of AChE activity of the control group and brain, liver, muscle and gill tissues of experimental group

\begin{tabular}{|l|l|c|c|c|}
\hline \multirow{4}{*}{ AChE } & Tissue & $\mathrm{F}$ & $\mathrm{R}^{2}$ & Significance \\
\hline \multirow{4}{*}{} & Brain & 624 & 0.99 & $<0.0001$ \\
\cline { 2 - 5 } & Liver & 353.9 & 0.98 & $<0.0001$ \\
\cline { 2 - 5 } & Muscle & 630.7 & 0.99 & $<0.0001$ \\
\cline { 2 - 5 } & Gills & 185.2 & 0.96 & $<0.0001$ \\
\hline
\end{tabular}

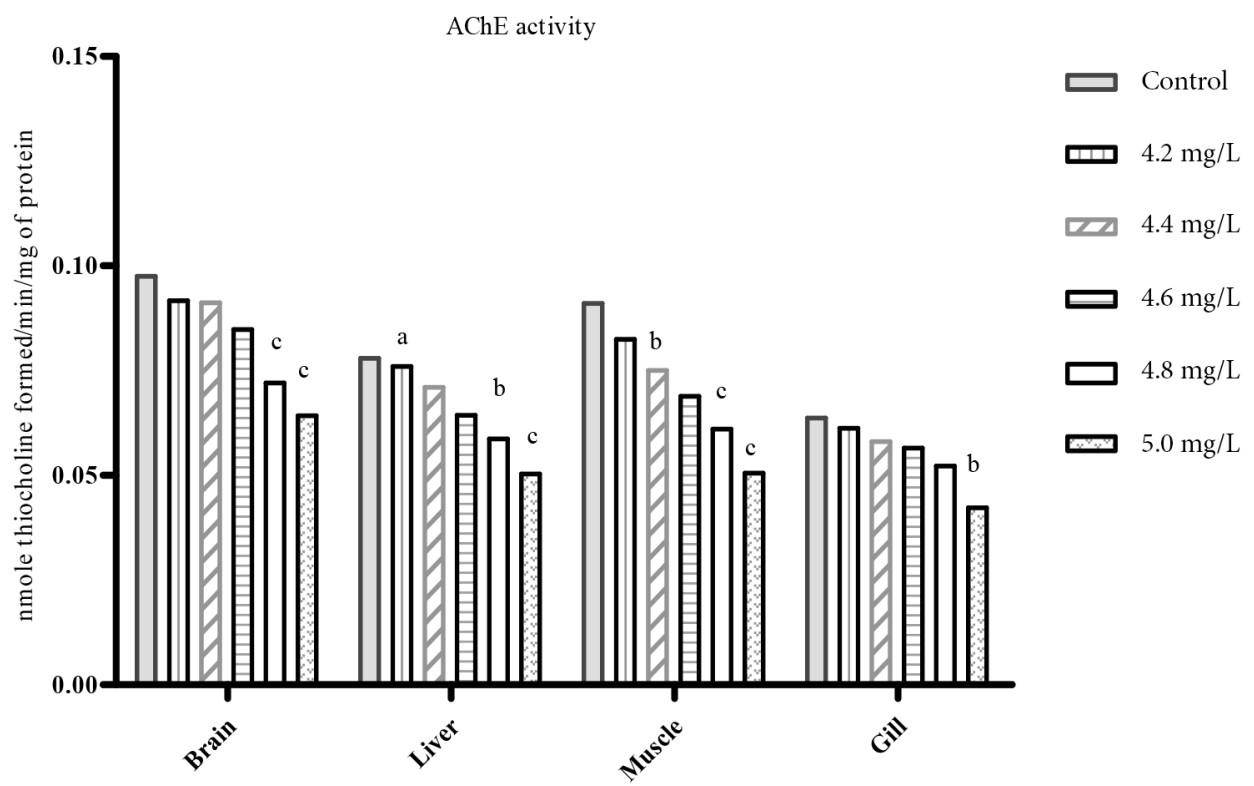

Figure 1. AChE activity in the tissues of $A$. testudineus after exposure to different concentrations of naphthalene. Values expressed as mean \pm SEM and alphabet superscripts are significantly different $(\mathrm{p} \leq 0.05)$ 


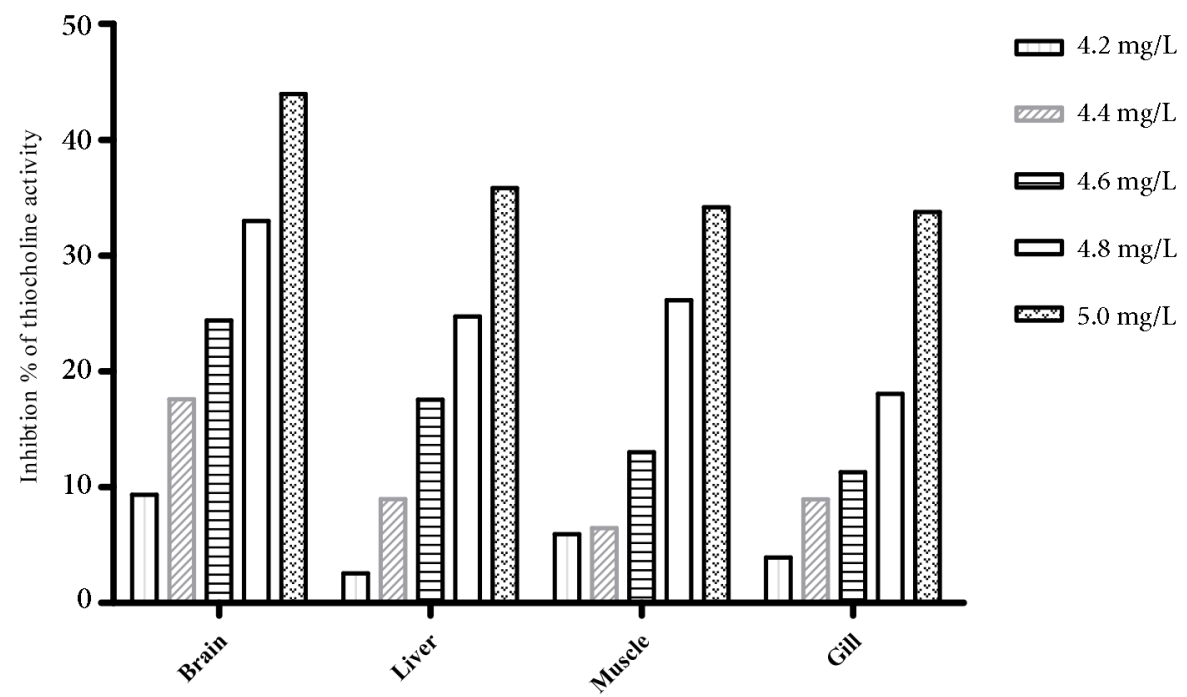

Figure 2. Percent inhibition of AChE activity in the tissues of the A. testudineus after exposure to different concentrations of naphthalene

\section{Results and discussion}

\subsection{Water analysis and acute toxicity test}

The average mean values of water quality parameters measured during the experiment were $\mathrm{pH} 7.56 \pm 0.10$, temperature $22.60 \pm 0.39{ }^{\circ} \mathrm{C}$, dissolved oxygen $5.12 \pm 0.57 \mathrm{mgL}^{-1}$, total hardness $161.2 \pm 0.87 \mathrm{mgL}^{-1}$ and alkalinity $146.4 \pm 0.76 \mathrm{mgL}^{-1}$ (Table 2). The $72 \mathrm{hr} \mathrm{LC}{ }_{50}$ for naphthalene in Anabas testudineus was found to be $5.4 \mathrm{mgL}^{-1}$ (Patnaik et al., 2016). The concentration of naphthalene in experimental medium was $0.006,0.008,0.019,0.056$, and $0.105 \mathrm{mgL}^{-1 .}$ Naphthalene is a low molecular weight polycyclic aromatic hydrocarbon less sensitive to photooxidation, as a result it remains persistent in surrounding water leading to bio-accumulation over a period of time (Ansari et al., 2010). There is very limited data on chronic exposure of aquatic animals to naphthalene. DeGraeve

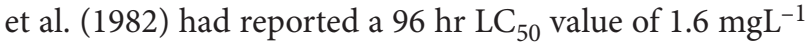
for rainbow trout and $7.9 \mathrm{mgL}^{-1}$ for fathead minnows. Ansari et al. (2010) had reported a $72 \mathrm{hr} \mathrm{LC}_{50}$ value of $1.56 \mathrm{mgL}^{-1}$ in juveniles of Metapenaeus affinis. Sogbanmu et al. (2018) had reported a $96 \mathrm{hr} \mathrm{LC} 50$ value of $7.21 \mathrm{mgL}^{-1}$ in Clarias gariepinus respectively. Similarly, Palanikumar et al. (2013) had reported a $72 \mathrm{hr} \mathrm{LC}_{50}$ value of $9.80 \mu \mathrm{gL}-1$ in juveniles of Chanos chanos.

Table 2 . Water quality parameters of the experimental tank

\begin{tabular}{|l|l|l|}
\hline \multicolumn{1}{|c|}{ Parameter } & \multicolumn{1}{c|}{ Method } & \multicolumn{1}{c|}{ Results } \\
\hline Temperature & Thermometric & $22.60 \pm 0.39^{\circ} \mathrm{C}$ \\
\hline $\mathrm{pH}$ & $\mathrm{pH}$ meter & $7.56 \pm 0.10$ \\
\hline $\begin{array}{l}\text { Dissolved } \\
\text { Oxygen }\end{array}$ & $\begin{array}{l}\text { Titrimetric (Winkler's } \\
\text { Method) }\end{array}$ & $5.12 \pm 0.57 \mathrm{mgL}^{-1}$ \\
\hline $\begin{array}{l}\text { Total } \\
\text { Hardness }\end{array}$ & Titrimetric & $161.2 \pm 0.87 \mathrm{mgL}^{-1}$ \\
\hline Alkalinity & Titrimetric & $146.4 \pm 0.76 \mathrm{mgL}^{-1}$ \\
\hline
\end{tabular}

\subsection{AChE activity}

Naphthalene was found to have an inhibitory effect on the activity of acetylcholinesterase in the tissues of the brain, liver, muscles, and gill. AChE activity decreased in a dose- dependent manner and the same was not observed in the case of the control set $(\mathrm{p}<0.05)$ (Figure 1, Table 1). AChE activity was measured and expressed as $\mathrm{n}$ moles of thiocholine formed $/ \mathrm{min} / \mathrm{mg}$ of protein. The decrease in AChE activity at different concentrations of naphthalene was recorded maximally in the brain $(-43.95 \%)$ followed by liver $(-35.81 \%)$, muscles $(-34.15 \%)$, and gills $(-33.75 \%)$ after exposure for a period of 72 hours (Figure 2). Range of inhibition of AChE was between $-9.34-43.95 \%$ in brain tissues, $2.56-35.81 \%$ in liver tissue, $5.94-34.15 \%$ in muscle tissue and $3.92-$ $33.75 \%$ in gills. The in-vivo effects of various pollutants like heavy metals, pesticides, dyes, etc have been extensively studied however there is dearth of information regarding the in-vivo effects of PAH naphthalene on AChE enzyme activity of aquatic organisms, despite its rampant use and presence in aquatic bodies. The results of the present study clearly demonstrate that the applied doses of naphthalene could induce a change in the AChE level in Anabas testudineus. Acetylcholinesterase (AChE) plays a very important role in neurotransmission by breaking neurotransmitter acetylcholine to choline and acetate. Inhibition of AChE leads to the accumulation of ACh and can alter nerve conduction pathways (Sturm et al., 1999). Acetylcholinesterase enzyme is crucial for spotting food, prey and equally required for monitoring of predator movement (Rani et al., 2017), and AChE accumulation in the brain causes over stimulation of cholinergic receptors resulting in a decline in neural and muscular control leading to change in normal behavioural patterns (Pereira et al., 2012). Constant accumulation of acetylcholine leads to twitching, quivering, seizures and paroxysms 
leading to the death of the aquatic organism (Sharbirde et al., 2011). AChE inhibition also affects the activity of ATPase enzyme involved in energy production and muscle contraction (Sen \& Karaytug, 2017). Similarly, fishes exposed to naphthalene exhibited a decrease in swimming activities and loss of buoyancy, which could be the result of decrease in the activity of the ATPase enzyme. Decreased AChE activity can damage the cell structure subsequently leading to lower expression of AChE in various tissues (Topal et al., 2016). The suppression of AChE activity in response to pollutants may also lead to an inflammatory response (Podolska \& Napierska, 2006). PAHs toxicity depends on its stability, lipophilicity and its ability to accumulate in fatty tissues (Oropesa et al., 2007). Recent work by Panda and Mahanta (2020) have reported the presence of naphthalene and other PAHs in Mahanadi Estuary at Paradeep, Odisha. The estuary is surrounded by industrial units and naphthalene concentration ranged from 0.9-3.2 ppb which was much higher than the WHO prescribed guidelines i.e $50 \mathrm{ng} / \mathrm{L}$. Few authors have stated that PAHs do not directly affect AChE activity, however, much clarity regarding the same is not available (Kopecka-Pilarczyk \& Correia, 2011). Various studies have been carried out to understand the inhibitory effect of AChE in aquatic animals in response to heavy metals, pesticides, and dyes (Sharbidre et al., 2011; Al-Ghais, 2013; Rickwood \& Galloway, 2004). European eel Anguilla Anguilla showed a decreased AChE activity in the liver and muscles which were concentrated with phenanthrene, naphthalene and anthracene. Interaction of xenobiotics leads to a positive correlation between inhibited enzyme activity and PAHs concentrations (Buet et al., 2006). Cholinesterases can provide important information about the physiological status of the exposed organism and environmental health (Jebali et al., 2013). The xenobiotics are capable of damaging the biological membranes which lead to various changes in cell metabolism. Studies carried out in sea birds as a result of the aftermath of Prestige oil tanker spill confirm the role of PAH as naphthalene and its alkyl derivate in inhibiting AChE activity (Oropesa et al., 2007). Similar changes have been observed in female Salmo trutta fishes on exposure to paper and pulp mill effluents containing PAHs (Payne et al., 1996). Work carried out by Lionetto et al. (2013) reported results on similar lines but the work has been carried out in-vitro (Lionetto et al., 2013). Thus, from the present study, it is evident that the exposure to naphthalene leads to significant changes in the AChE pathway of Anabas testudineus. The results highlight the role of $\mathrm{AChE}$ as an important and reliable biomarker in ecotoxicological studies. Biomarkers provide information about the biological effects of a certain type of pollutant and can be used to elucidate the relation of dose-effect in monitoring and health risk assessment (de Castilhos Ghisi, 2012). AChE activity assessment symbolizes biomarker of effect response due to measurable changes occurring within the organism.

\section{Conclusions}

Environmental pollution caused by different toxicants has become a matter of concern for aquatic organisms. The present study emphasizes the role of AChE as a significant biomarker, which can be used for understanding the toxic effect of other PAHs in the aquatic ecosystem. Biomonitoring studies involving biomarkers require a clear understanding of the relationship between exposure and response in the form of biochemical and neurological changes. AChE activity is generally inhibited and blocked by different toxicants. AChE can be used as one of the important biomarker tools signifying environmental contamination and its impact on the exposed organism.

\section{Acknowledgements}

The authors gratefully acknowledge the financial support in the form of a fellowship grant (S-SCSTMISC-0054-2018-1152) by Department of Science and Technology, Government of Odisha under Biju Patnaik Research Fellowship. Institutional support from Odisha Higher Education Programme for Excellence and Equity (OHPEE Grant no. HE-PTC-WB-02017) is appreciated. We are also thankful to the Head of the Department, Zoology for providing Infrastructural support for carrying out the research work.

\section{Author contributions}

Susri Nayak carried out the experimental work (Biochemical, and HPLC), finalization of results and preparation of the manuscript. Lipika Patnaik designed the experiment, helped in the preparation, editing and finalization of the manuscript.

\section{Conflict of interest}

The authors declare no conflict of interest.

\section{References}

Al-Ghais, S. M. (2013). Acetylcholinesterase, glutathione and hepatosomatic index as potential biomarkers of sewage pollution and depuration in fish. Marine Pollution Bulletin, 74(1), 183-186. https://doi.org/10.1016/j.marpolbul.2013.07.005

Aly, S. T., Kanaan, D. M., El-Dieb, A. S., \& Abu-Eishah, S. I. (2018). Properties of ceramic waste powder-based geopolymer concrete. In International Congress on Polymers in Concrete (ICPIC 2018) (pp. 429-435). Springer.

https://doi.org/10.1007/978-3-319-78175-4_54

American Public Health Association. (2005). Standard methods for the examination of water and wastewater. American Public Health Association/American Water Works Association/ Water Environment Federation. Washington, DC.

Ansari, Z. A., Farshchi, P., \& Faniband, M. (2010). Naphthalene induced activities on growth, respiratory metabolism and biochemical composition in juveniles of Metapenaeus affinis (H. Milne Edward, 1837). Indian Journal of Marine Sciences, 39(2), 285-289. 
Armstrong, B., Hutchinson, E., Unwin, J., \& Fletcher, T. (2004). Lung cancer risk after exposure to polycyclic aromatic hydrocarbons: A review and meta-analysis. Environmental Health Perspectives, 112(9), 970-978.

https://doi.org/10.1289/ehp.6895

Athira, N., \& Jaya, D. S. (2018). The use of fish biomarkers for assessing textile effluent contamination of aquatic ecosystems: A review. Nature Environment and Pollution Technology, 17(1), 25-34.

Balakumaran, M., Cyril Xavier, T., Ponmathan, K. P., Praveen, K. J., \& Ganesh K. M. (2015). Comparative studies on floor tiles using geopolymer concrete and cement concrete. International Journal of Engineering Research \& Technology, 3(11), 1-4.

Buet, A., Banas, D., Vollaire, Y., Coulet, E., \& Roche, H. (2006). Biomarker responses in European eel (Anguilla anguilla) exposed to persistent organic pollutants. A field study in the Vaccarès lagoon (Camargue, France). Chemosphere, 65(10), 1846-1858.

https://doi.org/10.1016/j.chemosphere.2006.03.074

de Castilhos Ghisi, N. (2012). Relationship between biomarkers and pesticide exposure in fishes: A review. In R. P. Soundararajan (Ed.), Pesticides - Advances in chemical and botanical pesticides (pp. 357-382). InTech. https://doi.org/10.5772/48604

DeGraeve, G. M., Elder, R. G., Woods, D. C., \& Bergman, H. L. (1982). Effects of naphthalene and benzene on fathead minnows and rainbow trout. Archives of Environmental Contamination and Toxicology, 11(4), 487-490.

https://doi.org/10.1007/BF01056076

Dey, S., Samanta, P., Mondal, N. S., Kole, D., Mandal, A., Patra, A., \& Ghosh, A. R. (2019). Dose specific responses of Anabas testudineus (Bloch) to anthracene (PAH): Haematological and biochemical manifestation. Emerging Contaminants, 5, 232-239. https://doi.org/10.1016/j.emcon.2019.07.001

Ellman, G. L., Courtney, K. D., Andres Jr, V., \& Featherstone, R. M. (1961). A new and rapid colorimetric determination of acetylcholinesterase activity. Biochemical Pharmacology, 7(2), 88-95.

https://doi.org/10.1016/0006-2952(61)90145-9

Finney, D. J. (1971). Probit analysis ( ${ }^{\text {rd }}$ ed.). Cambridge University Press.

Fulton, M. H., \& Key, P. B. (2001). Acetylcholinesterase inhibition in estuarine fish and invertebrates as an indicator of organophosphorus insecticide exposure and effects. Environmental Toxicology and Chemistry: An International Journal, 20(1), 37-45. https://doi.org/10.1002/etc.5620200104

Gupta, V. K., Kumar, A., Yadav, S. H., Pandey, R., \& Sharma, B. (2017). Acetylcholinesterase as a biomarker of arsenic induced cardiotoxicity in mammals. Science International, 5(4), 142-149. https://doi.org/10.17311/sciintl.2017.142.149

Hauser-Davis, R. A., Lopes, R. M., \& Ziolli, R. L. (2019). Inihibition of mullet (M. liza) brain acetylcholinesterase activity by in vitro polycyclic aromatic hydrocarbon exposure. Marine Pollution Bulletin, 140, 30-34.

https://doi.org/10.1016/j.marpolbul.2019.01.027

Hossain, M. A., Yeasmin, F., Rahman, S. M., \& Rana, S. (2014). Naphthalene, a polycyclic aromatic hydrocarbon, in the fish samples from the Bangsai river of Bangladesh by gas chromatograph-mass spectrometry. Arabian Journal of Chemistry, 7(6), 976-980. https://doi.org/10.1016/j.arabjc.2010.12.014

Jebali, J., Khedher, S. B., Sabbagh, M., Kamel, N., Banni, M., \& Boussetta, H. (2013). Cholinesterase activity as biomarker of neurotoxicity: Utility in the assessment of aquatic environment contamination. Revista de Gestão Costeira Integrada-
Journal of Integrated Coastal Zone Management, 13(4), 525537. https://doi.org/10.5894/rgci430

Kopecka-Pilarczyk, J., \& Correia, A. D. (2011). Effects of exposure to PAHs on brain AChE in gilthead seabream, Sparus aurata L., under laboratory conditions. Bulletin of Environmental Contamination and Toxicology, 86(4), 379-383.

https://doi.org/10.1007/s00128-011-0234-y

Latimer, J. S., \& Zheng, J. (2003). The sources, transport, and fate of PAHs in the marine environment. In P. E. T. Douben (Ed.), PAHs: An ecological perspective (pp. 9-33). John Wiley \& Sons Inc.

Lionetto, M. G., Caricato, R., Calisi, A., Giordano, M. E., \& Schettino, T. (2013). Acetylcholinesterase as a biomarker in environmental and occupational medicine: New insights and future perspectives. BioMed Research International, 2013, 321213. https://doi.org/10.1155/2013/321213

Lowry, O. H., Rosebrough, N. J., Farr, A. L., \& Randall, R. J. (1951). Protein measurement with the Folin phenol reagent. Journal of Biological Chemistry, 193(1), 265-275. https://doi.org/10.1016/S0021-9258(19)52451-6

Mary, S. C. H., Silvan, S., \& Elumalai, E. K. (2014). Toxicology study on lead nitrate induced fresh water fish Cirrhinus mrigala (Hamilton). European Journal of Academic Essays, 1(7), 5-8.

Mehra, S., \& Chadha, P. (2020). Bioaccumulation and toxicity of 2-naphthalene sulfonate: An intermediate compound used in textile industry. Toxicology Research, 9(2), 127-136.

https://doi.org/10.1093/toxres/tfaa008

Oropesa, A. L., Pérez-López, M., Hernández, D., García, J. P., Fidalgo, L. E., López-Beceiro, A., \& Soler, F. (2007). Acetylcholinesterase activity in seabirds affected by the Prestige oil spill on the Galician coast (NW Spain). Science of the Total Environment, 372(2-3), 532-538.

https://doi.org/10.1016/j.scitotenv.2006.09.006

Palanikumar, L., Kumaraguru, A. K., \& Ramakritinan, C. M. (2013). Biochemical and genotoxic response of naphthalene to fingerlings of milkfish Chanos chanos. Ecotoxicology, 22(7), 1111-1122. https://doi.org/10.1007/s10646-013-1098-1

Panda, B. S., \& Mahanta, S. K. (2020). Quantification of poly aromatic hydrocarbons in waters of Mahanadi estuary at Paradeep, Odisha. International Research Journal of Engineering and Technology, 7(6), 6971-6981.

Patnaik, L., Raut, D., Panda, D., \& Nayak, S. (2016). Naphthalene induced Biochemical changes in Anabas testudineus. Journal of Biodiversity and Environment Sciences, 8(2), 154-158.

Payne, J. F., Mathieu, A., Melvin, W., \& Fancey, L. L. (1996). Acetylcholinesterase, an old biomarker with a new future? Field trials in association with two urban rivers and a paper mill in Newfoundland. Marine Pollution Bulletin, 32(2), 225-231. https://doi.org/10.1016/0025-326X(95)00112-Z

Pereira, V. M., Bortolotto, J. W., Kist, L. W., de Azevedo, M. B., Fritsch, R. S., da Luz Oliveira, R., Pereira, T. C. B., Bonan, C. D., Vianna, M. R., \& Bogo, M. R. (2012). Endosulfan exposure inhibits brain AChE activity and impairs swimming performance in adult zebrafish (Danio rerio). Neurotoxicology, 33(3), 469-475. https://doi.org/10.1016/j.neuro.2012.03.005

Pikkarainen, A. L. (2006). Ethoxyresorufin-O-deethylase (EROD) activity and bile metabolites as contamination indicators in Baltic Sea perch: Determination by HPLC. Chemosphere, 65(10), 1888-1897.

https://doi.org/10.1016/j.chemosphere.2006.03.066

Podolska, M., \& Napierska, D. (2006). Acetylcholinesterase activity in hosts (herring Clupea harengus) and parasites (Anisakis simplex larvae) from the southern Baltic. ICES Journal of 
Marine Science, 63(1), 161-168.

https://doi.org/10.1016/j.icesjms.2005.08.001

Rani, S., Gupta, R. K., \& Yadav, J. (2017). Heavy metal induced alterations in acetylcholinesterase activity of Indian major carps. Journal of Entomology and Zoology Studies, 5(4), 818-821.

Rickwood, C. J., \& Galloway, T. S. (2004). Acetylcholinesterase inhibition as a biomarker of adverse effect: A study of Mytilus edulis exposed to the priority pollutant chlorfenvinphos. Aquatic Toxicology, 67(1), 45-56. https://doi.org/10.1016/j.aquatox.2003.11.004

Şen, G., \& Karaytuğ, S. (2017). Effects of lead and selenium interaction on acetylcholinesterase activity in brain and accumulation of metal in tissues of Oreochromis niloticus (L., 1758). Natural and Engineering Sciences, 2(2), 21-32. https://doi.org/10.28978/nesciences.328857

Sharbidre, A. A., Metkari, V., \& ka Patode, P. (2011). Effect of diazinon on acetylcholinesterase activity and lipid peroxidation of Poecilia reticulate. Research Journal of Environmental Toxicology, 5(2), 152-161.

https://doi.org/10.3923/rjet.2011.152.161

Shenai, V. A. (2001). Non-ecofriendly textile chemicals and their probable substitutes - An overview. Indian Journal of Fibre and Textile Research, 26, 50-54.

Sivaram, N. M., Gopal, P. M., \& Barik, D. (2019). Toxic waste from textile industries. In Energy from toxic organic waste for heat and power generation (pp. 43-54). Woodhead Publishing. https://doi.org/10.1016/B978-0-08-102528-4.00004-3

Sogbanmu, T. O., Osibona, A. O., Oguntunde, O. A., \& Otitoloju, A. A. (2018). Biomarkers of toxicity in Clarias gariepinus exposed to sublethal concentrations of polycyclic aromatic hydrocarbons. African Journal of Aquatic Science, 43(3), 281292. https://doi.org/10.2989/16085914.2018.1491825
Sturm, A., De Assis, H. D. S., \& Hansen, P. D. (1999). Cholinesterases of marine teleost fish: Enzymological characterization and potential use in the monitoring of neurotoxic contamination. Marine Environmental Research, 47(4), 389-398. https://doi.org/10.1016/S0141-1136(98)00127-5

Topal, A., Şişecioğlu, M., Atamanalp, M., Işık, A., \& Yılmaz, B. (2016). The in vitro and in vivo effects of chlorpyrifos on acetylcholinesterase activity of rainbow trout brain. Journal of Applied Animal Research, 44(1), 243-247. https://doi.org/10.1080/09712119.2015.1031776

Walker, C. H., Sibly, R. M., Hopkin, S. P., \& Peakall, D. B. (2012). Principles of ecotoxicology ( $4^{\text {th }} \mathrm{ed}$.). CRC Press.

Whittaker, M. (1980). Plasma cholinesterase variants and the anaesthetist. Anaesthesia, 35(2), 174-197. https://doi.org/10.1111/j.1365-2044.1980.tb03800.x

Vijayavel, K., Anbuselvam, C., Balasubramanian, M. P., Samuel, V. D., \& Gopalakrishnan, S. (2006). Assessment of biochemical components and enzyme activities in the estuarine crab Scylla tranquebarica from naphthalene contaminated habitants. Ecotoxicology, 15(5), 469-476. https://doi.org/10.1007/s10646-006-0082-4

Zhang, Y. M., Guo, G. Z., La Zhang, L., \& Song, J. H. (2019). Synthesis, analysis and application of naphthalene sulfonic acid formaldehyde condensate. In IOP Conference Series: Earth and Environmental Science, 237(2). IOP Publishing. https://doi.org/10.1088/1755-1315/237/2/022029

Zulfahmi, I., Muliari, M., Akmal, Y., \& Batubara, A. S. (2018). Reproductive performance and gonad histopathology of female Nile tilapia (Oreochromis niloticus Linnaeus 1758) exposed to palm oil mill effluent. The Egyptian Journal of Aquatic Research, 44(4), 327-332. https://doi.org/10.1016/j.ejar.2018.09.003 